\title{
SETTING THE DISTANCE : \\ THEORETICAL PRACTICE OF MILAN ZLOKOVIĆ AND ITS MATERIAL COROLLARIES
}

\begin{abstract}
A B S T R A C T
In architectural practice of Milan Zloković there exists a curious division between his prewar orientation towards building and his postwar emphasis on theoretical research. However, the distinction between these two fields of his work is not that simple and unequivocal. The particular aim of this paper is to explore this vague relationship in Zloković's postwar practice by focusing on his late project of the Tourist Settlement in Ulcinj and the previous preparatory work at the Institute of Architecture and Urban Planning in Belgrade. The analysis reveals Zloković's precise understanding of concrete problems of contemporariness and exposes his position in the specific context of Yugoslav modernism as truly autonomous yet deeply engaged.
\end{abstract}


When the text of Milan and Đorđe Zloković "The Significance of Modular Coordination in Building Design and Construction" was published in 1961 in the magazine Produktivnost (Productivity) ${ }^{1}$ the international debate on the role of proportional systems in architecture had already been concluded. After ten years of the vivid interest of the professional public in this theme, the debacle of the motion at the RIBA (Royal Institute of British Architects) meeting in London on 18 June, 1957 marked the turning point in this debate and hinted at progressing skepticism of the architects in view of the application of proportional systems in architectural designing. ${ }^{2}$ In the first postwar years this interest was motivated by the requirement for the quick and efficient renovation of the destroyed cities, as well as by the significant economic and social reforms which placed the requirements of the progress and modernization as the priority plan. In England, where the epicenter of this debate was, the preoccupation of the architects with the proportional systems and modular coordination coincided with the period of Labor party government of Clement Attlee and the "Welfare State" policy of building, and the declining interest, according to the researches of Eva-Marie Neumann, started with the victory of the Conservative party at the election in 1951, and with rescinding the system of architects licensing. ${ }^{3}$

However, at the beginning of ninety-sixties, the problems of building industrialization and construction elements standardization were still in the focus of attention of the Yugoslav architects and urbanists. The first buildings erected from pre-fabricated elements had already been built at that time, but the results of building industry modernization would only be evident during the following two decades and would be measured by thousands of residential and public buildings constructed within rather short terms, applying contemporary building methods. ${ }^{4}$ Within this context, the above mentioned study of Milan and Đorđe Zloković, in the concrete brief of the construction of the tourist buildings in Montenegro coast, provided an example of the practical application of the system of modular coordination in architectural design. Originating as the result of the researches made during 1960 at the Institute of Architecture and Urbainsm of Serbia (IAUS), this scientific paper in the bibliography of Milan Zloković may be distinguished as the one that in the most direct way bridges the gap between the theoretical and practical discourse, namely establishes the relation between some of his previous theoretical researches and the last realized design, the Tourist settlement in Ulcinj. ${ }^{5}$ Even though only implicitly indicated, the relations between these two domains of Zloković's professional activity during the period between the two World Wars were of substantial significance in articulation of his designing method. ${ }^{6}$ In the works that 


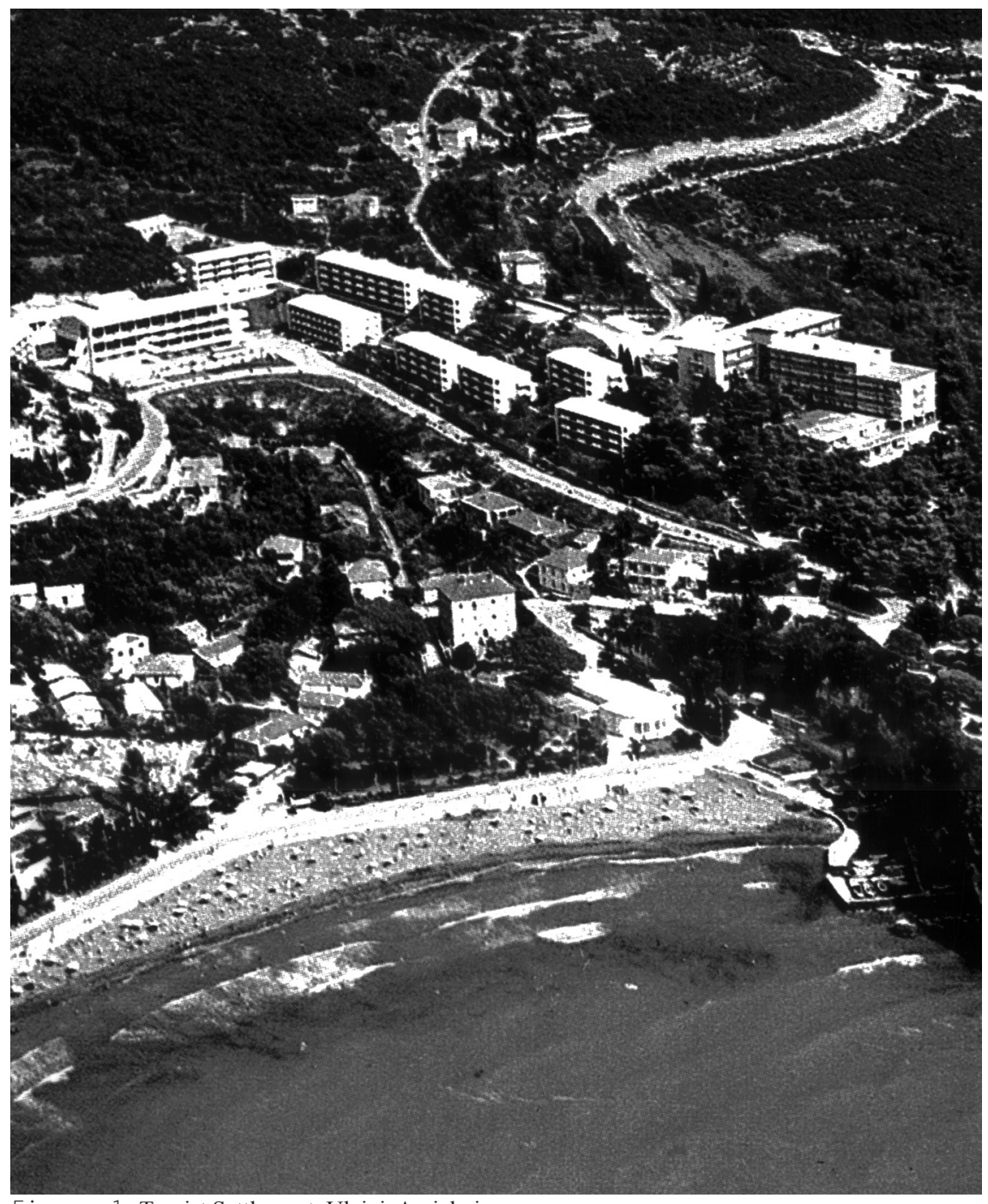

Figure 1 Tourist Settlement, Ulcinj. Aerial view. 
originated at the end of ninety-fifties and the beginning of ninety-sixties, Zloković, however, explicitly insisted on establishing these relations and realized them in a new and different manner. Starting from this premise, this paper will explore the character of this change.

According to Bogdan Bogdanović, Zloković's many-years long theoretical work received its practical affirmation at the beginning of ninety-sixties:

At that time Zloković was the first in Yugoslavia, and among the first ones in general, to undertake to develop and propose the numerical codification of measures and elements of contemporary architecture. Given that he was a builder of great experience he, unlike Hambige, or Moessel, or Ghyka, did not dwell only on the abstract side of the problem of proportions and measures. (...). The preoccupations of Zloković, which initially to some seemed superfluous, and which many, even receptively took only as a game, received in the past years remarkably practical affirmation. The introduction of the anthropomorphic element in the system of modular coordination proved as a fruitful creative action which not only facilitates functional and compositional manipulation with contemporary building elements, but to a great degree facilitates, and even conditions the proper typification and prefabrication of elements. ${ }^{7}$

Written on the occasion of conferring the award for the life-work to Milan Zloković in 1963, this Bogdanović's text is about the curios change in the reception of Zloković's theoretical work. However, if we try to follow Bogdanović's remark on "remarkably practical affirmation", it gives rise to the question to which extent and in which manner Zloković's theory influenced this practice and in reality what was its role in planned building industrialization? According to the insights of the historians, Zloković's position in the changed socio-political conditions of the postwar Yugoslavia was marginal: although he continued participating at public competitions and receiving numerous awards and recognitions at them, during this period Zloković realized only few designs. ${ }^{8}$ His principle standpoint on the requirement of introduction of the new methods in contemporary design method was for the first time explicitly formulated by him at the First Symposium of the Architects and Urbanists of Yugoslavia in Dubrovnik, in 1950. According to him, this proposal was received with the coolness on the part of the designers, same like a year later Le Corbusier's ideas on introduction of the universal scale rule, modulor, was also met with a limited response at the First International Congress on Proportions in art held in Milan. ${ }^{9}$ Nikola Dobrović in the text "Animomorphic creative process" explicitly expressed this distrust: 
Anthropomorphic - human form measuring - aspirations and images, as well as any discussion about them, are advisable to be once for all excluded from the creator's spiritual structure. They can remain only as reminiscences of the past, the milestone in the development of the human thought, and maybe as a means in the fight with the representatives of the scientific aesthetics. ${ }^{10}$

Like in the international debate as well, the ideas on introduction of modular system in designing were understood as a threat, the danger faced in respect to limitation of creative freedom of the architects. Due to its historical founding, the theory of proportions has met with the lack of understanding among the modern architects, which is testified also by Dobrović's outspoken criticism. Based on these insights, it could rather be presumed that Zloković's influence upon the architectural practice in the postwar Yugoslavia was limited and indirect and that its effect was manifested first of all through the instructional process at the Faculty of Architecture in Belgrade and through the published texts. This situation where Zloković's work simultaneously emerges both as the key and the marginal phenomenon within the context of the postwar Yugoslav modernism gives rise to a question regarding the character of his relations towards the contemporary social practice. This relation, as the hypothesis of this research, would be marked as dually coded, simultaneously being autonomous and committed. In other words, although seemingly remote from the social reality, Zloković's theory of proportions was not only a suitable means for protection of professional competencies and the instrument of fight against a dehumanizing effect of the uncontrolled industrialization: it was an authentic product of that concrete social reality.

The existing historiography provides an extensive insight into Zloković's designs and realized buildings which originated in the period between the two World Wars, however there are only general considerations ${ }^{11}$ of the works which originated between 1945 and 1965. In the absence of the more detailed studies, the designs and realized buildings from this period are generally labeled as less successful than the previous ones. For example, Marina Đurđevic writes that following the end of the World War Two, Zloković's creative potential was exhausted within the field of theory, and remarks that the "(p)eriod of the renewal and construction" was not the opportunity for exposing the creativity in any form whatsoever", and that the "(de)socialization of all fields of creativity, collectivism and politicization of architecture narrowed down the space for the work of the architects individuals and killed any aspiration towards the unique architectural expression." 12 The last Zloković's realized designs were 
interpreted in Zoran Manević's text as the reversal to the classic themes from the preceding period:

In his late works, such as the Teacher Training School in Prizren or the Tourist settlement in Ulcinj, the works he realized and signed together with his son and his daughter, dr. Đorđe Zloković and Milica Mojović, respectively, he noticed how these ideal modular schemes, when transposed into buildings, lose their impersonality and begin revealing the hidden ideas of its author. Did he at that time think - as it occurs to the historian - how the forms of the Teacher Training School in Prizren were reminiscent of the Karajović Board and lodging (in Mataruška Banja) dating long ago in 1932, and this one in turn, was reminiscent of the competition work for the Artistic Pavilion ("Cvijeta Zuzorić" in Belgrade) dated even earlier in 1925."13

Starting from these pioneers researches, the intention of this paper, within the extensive dissertation on relations between Zloković's architectural theory and design practice, is to research in more detail the case of the Tourist settlement, namely hotel "Mediteran" in Ulcinj, as well as the role of the scientific study which preceded it.

\section{THEORETICAL DISCOURSE:}

\section{BETWEEN THE ABSTRACTION AND PRODUCTIVITY}

Zloković's intensive work within the field of architectural theory begun during the World War Two, as the radical interruption of the active designer practice, the discontinuity marking the absolute separation from the unacceptable social reality. At the same time, occupied with the fundamental, mathematical problems in architectural design, Zloković, same like Le Corbsuier in collaboration with the association ASCORAL, anticipated the future changes and the potential significance of these researches within the context of postwar renovation and construction. The war devastations again hinted at the opportunity to realize the ideas on series production which Le Corbusier, upon the end of the World War One, explicitly presented in the magazine L'Esprit Nouveau: "Heavy industry should turn its attention to building and standardize the elements of the house. We must create a mass-production state of mind. A state of mind for building mass-production housing. A state of mind for living in mass-produced housing. A state of mind for conceiving mass-production housing." 14 Le Corbusier's texts and designs will in continuity present the key reference in Zloković's researches. "I dream of placing one "network of proportions" at the locations at which one day the construction will be carried out throughout our country", 
wrote Le Corbusier on his intentions of $1943 .{ }^{15}$ Based on the texts published by Zloković following the end of the war, it could be remarked that Zloković's dreams at the time coincided with Le Corbusier's and his theoretical starting points could be recognized exactly in this coincidence.

Regardless of the extent to which Zloković's researches were orientated towards the abstract themes of architecture or seemingly remote historical phenomena, the contemporary problems rested in their background. His first text which on the scientific grounds dealt with the theory of proportions "The Influence of the Proportional System of Blondel's gate of SaintDenis in Paris upon the Insufficiently Clarified Problem of Proportions in Architecture", was devoted by Zloković to the architecture of the epoch of rationalism. ${ }^{16}$ The selection of François Blondel's gate as the subject of the analysis was motivated by le Corbusier's proportional diagram which was published in the book Towards the Real Architecture, being the first in series of examples illustrating the role and significance of the regulative lines (tracés régulateurs) in architectural design. Perceiving the difference between the classic principles of proportioning and Le Corbuiser's method, which, as written by Zloković, was mainly based on the principle of analogy, the author undertook a detailed proportional analysis of the designed and asbuilt Blondel's triumphal arc and arrived to the conclusions which were "over and above concrete in order to be able to deny their overall significance". ${ }^{17}$ The text was prepared and submitted for printing in mid 1946, and published in 1949, at the same time as Modulor ${ }^{18}$.

The focal place of Zloković's theoretical discourse is taken by the study of "golden section" phenomenon, namely the mechanism of uninterrupted division, being the anthropomorphic and most flexible of the known proportional systems. Unlike the majority of theoreticians of proportions, including Le Corbusier as well, whose modulor was also conceived as the systematic generator of this proportional relation, in his rigorous mathematical analyses Zloković did not leave space to mysticism or esotericism. As pointed out by Richard Padovan, le Corbusier's texts were full of exceptional perceptions, however, their consistency did not rest that much on rational arguments, as much on rhetoric takeoff. ${ }^{19}$ The very modulor was derived from incorrectly set mathematical problem, and the explanation which subsequently, at the end of the book, was provided by professor René Taton, Le Corbusier managed cunningly to interpret as the affirmation of his initial hypothesis. 
On the other hand, Zlokovićs work was systematic and mathematically impeccable. Relying on Le Corbusier's visionary conceptions and theoretical suppositions, Zloković in his researches dealt with their detailed analysis, corrected them and added preciseness and consistency to them. ${ }^{20}$

Given that the analysis of the structure and the broader context of Zlokovićs work within the field of theory of proportions by far exceed the scope of this research, at this point only several key moments would be singled out and certain structural regularities recognized. Besides Blondel's gate, the subject of Zloković's fundamental researches were carefully selected historical phenomena: The Roman compasses in the ancient times, the drawings in the tractate De Divina Prorpotione by Fra Luca Pacioli, the civic houses in Boka Kotorska, Korčula and Dubrovnik, architectural orders per Vignola. ${ }^{21}$ From these, fundamental researches, detailed mathematical analyses were derived of the two key proportional systems, the harmonious proportions, on one part, and the mechanism of uninterrupted division, on the other part, as well as their iner-relations.

Shifting the focus from the mathematical to the concrete problems of designing was effected successively, however, actually, both discourses in continuity were present in diverse correlations. It was already in his report for the First Consultation of the Architects and Urban Planners of Yugoslavia in 1950, that Zloković directly linked his theoretical work to the concrete problems of modernism and laid down the central theme of the entire research: the problem of modular coordination of measures in architectural design. Starting from the arbitration of the metric system of measures and indicating the significance of the anthropomorphic measures in designing and building, Zloković, as per the recommendations of Ernst Neufert, advocated for the application of octametric system of measures and worked on adjustment of international standards. ${ }^{22}$ The last level of Zloković's researches comprised the work on operationalization and application of the theoretical knowledge. The text dated 1955 proposing the corrections of the modular measures of the standard building elements, Durisol blocks, ${ }^{23}$ belongs to this group of texts, as well as the article describing in detail the principles of designing and construction of the first building in Yugoslavia in which the method of modular coordination was implemented systematically, the Teacher Training School in Prizren. ${ }^{24}$ The text which is the direct subject of this research, "The Significance of Modular Coordination in Building Design and Construction", is the last in series of Zloković's theoretical papers in which he directly approached the problems of architectural design practice. 


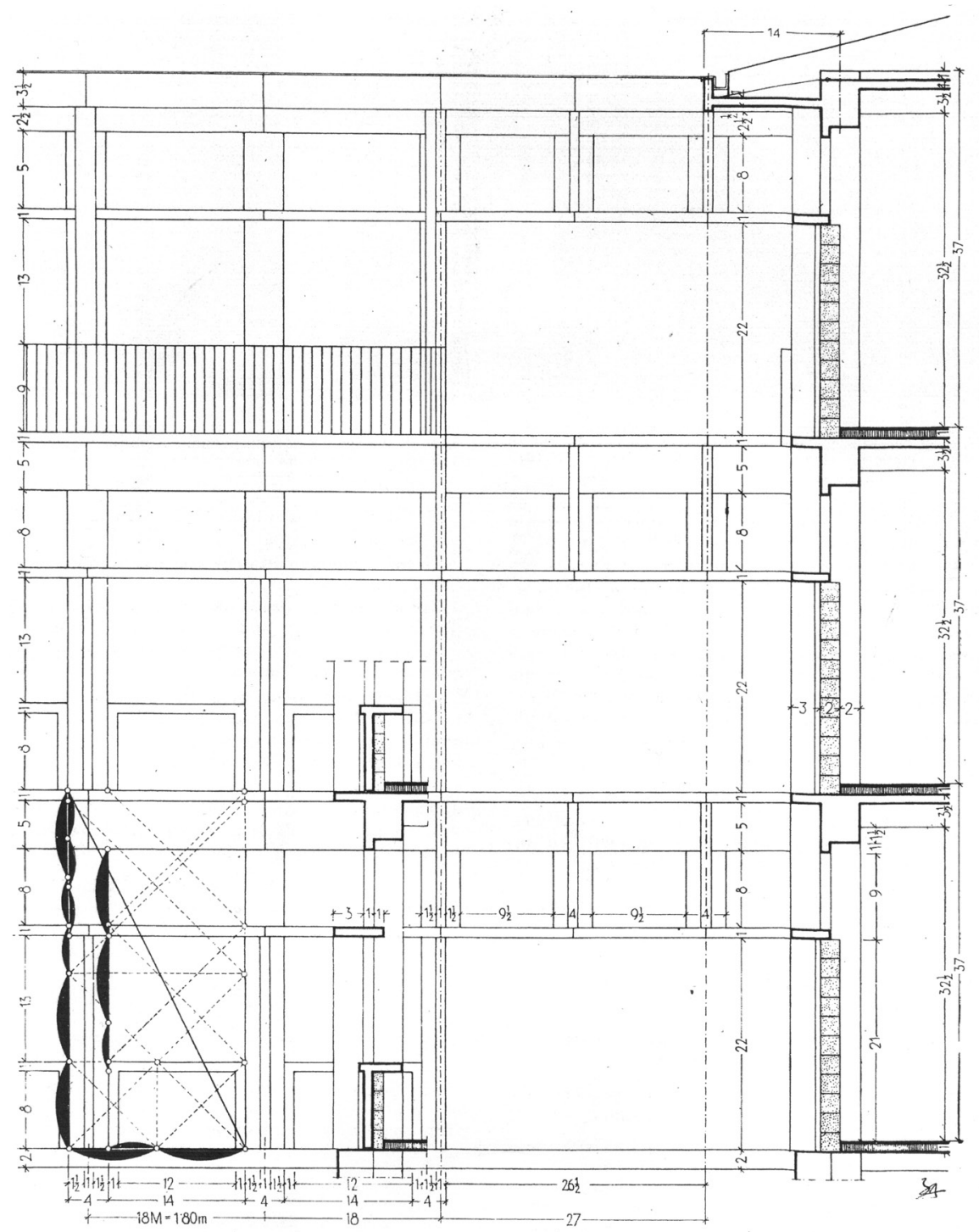

Figure 2

Milan Zloković, Teacher Training School in Prizren. Proportional diagram of the main facade elements. 
Through this study which deals with the research and typification of the tourist buildings at Montenegro coast, the authors established the complex insight into specific aspects of the time and the space and proposed radical change in methodology of designing and building. The work of Milan and Đorđe Zloković at the Institute of Architecture and Urban Planning of Serbia and the construction of the hotel "Mediteran" can be perceived only as the part of the broader process of the planned construction of the Yugoslav coast. Namely, according to the author, the researches were initiated by the National Boards of Budva and Ulcinj, preparing concrete application of the results at three locations in this regions: at the Zavala peninsula, and at two locations in Ulcinj. The Mediterranean hedonist utopia at the beginning of the ninetysixties became the integral part of the reality of the Yugoslav socialist society. With the emergence of the new habits and with the increase of the personal standard of living, there came to increased investment of the community in this field of economy and mass construction of hotels, boardinghouses and tourist settlements at the Adriatic coast commenced. In order to direct this process and prevent the unorganized and uncontrolled construction and devastation of the natural resources, the experts within diverse federal, republic and regional institutions initiated and implemented to a great extent the necessary researches: the analyses of the existing state were made, objectives of development specified, spatial and economic capacities determined as well as the basic concept on their location. For certain regions the regional spatial plans were prepared and adopted, and within the relatively short period of time, a series of tourist buildings of high architectural standard was constructed. ${ }^{25}$

The researches of Milan and Đorđe Zloković were incited by the concrete problems arising from the real limitations in implementation of these plans: insufficiently well-considered organization of the construction sites, nonrational postulates of the design studies, barely existing cooperation of the operations sector with the insufficiently developed building industry. The authors remarked that the result was the slow construction which resulted in increase of the price per $\mathrm{m}^{2}$ of the built area and they presented their researches as the work on overcoming these problems. The changes proposed by them were radical and systematic ones and required pre-orientation in the very manner of designing and construction, in compliance with the old requirement of the Modern movement:

The essential knowledge is that the modern building with its greatest part should present a set of the skillfully combined prefabricated construction elements. The moment has come when the specialized trade production should be replaced with the industrial prefabricated elements. Only the 
radical change of the contractors technique would enable expediting and decrease in price of building construction. ${ }^{26}$

Opposing the objection on inhibition of the creative freedom of the designers, Milan and Đorđe Zloković proposed the "flexible typification" of the related buildings, with an intention to achieve "the optimal solutions" in view of the function, aesthetics, efficiency in prefabrication and exploitation possibilities. ${ }^{27}$ Based on the previous researches within this field, the authors decided on the utilization of the discontinuous modular network, basic module of $1 \mathrm{M}=10 \mathrm{~cm}$, the design module of $1 \mathrm{M}_{6}=6 \mathrm{M}=60 \mathrm{~cm}$ and modular spans of $36 \mathrm{M}, 42 \mathrm{M}, 48 \mathrm{M}, 54 \mathrm{M}$ и $60 \mathrm{M}$. The structural system is based on the bearing walls laid out perpendicularly upon the direction of the building stretching, which provides good audio insulation between the hotel rooms and facilities in construction of façade elements. The buildings consist of a series of lamellas which simultaneously represent structural and functional units and make standardization of building elements and typification of accommodation units possible, and the diversity of entities is obtained by combinations of lamellas formed of the limited, minimum number of prefabricated construction elements. In that way the open mathematical system, precisely determined and potentially unlimited, was formed: "the units are thus designed" was written by the authors, "that it is possible to set in rows the same or diverse units lengthwise or vertically and depth-way shearing - in the infinite number of combinations." ${ }^{28}$

On the basis of the comparative analysis of four types of hotel units (suites, hotel rooms, bungalows and separate rooms) the authors decided on the type of suites due, as already mentioned, to greater comfort, less built area per bed and greater value in exploitation. The suites were designed as independent units with complete sanitary facilities and separate entrance from outside which made it possible to avoid long hotel corridors and to achieve high level of independence within rationally organized entity, maximum autonomy of the individual unit and abounding of common public functions was compensated for by limitations in respect to the size of the individual space. The basic type was a three-bed suite which was structured as an elongated lamella the segments of which were: in-depth loggia, large bedroom, bathroom/ante-room and smaller bedroom. At the ends of the tract, the apartments had the entrance from the gable side which enabled organization of four-bed suite, whereas in the ground-floor, by the reduction of the basic type, a two-bed suite with naturally ventilated bathroom was achieved. In this way within the assumed system of equality the possibility of differentiation was provided, namely 


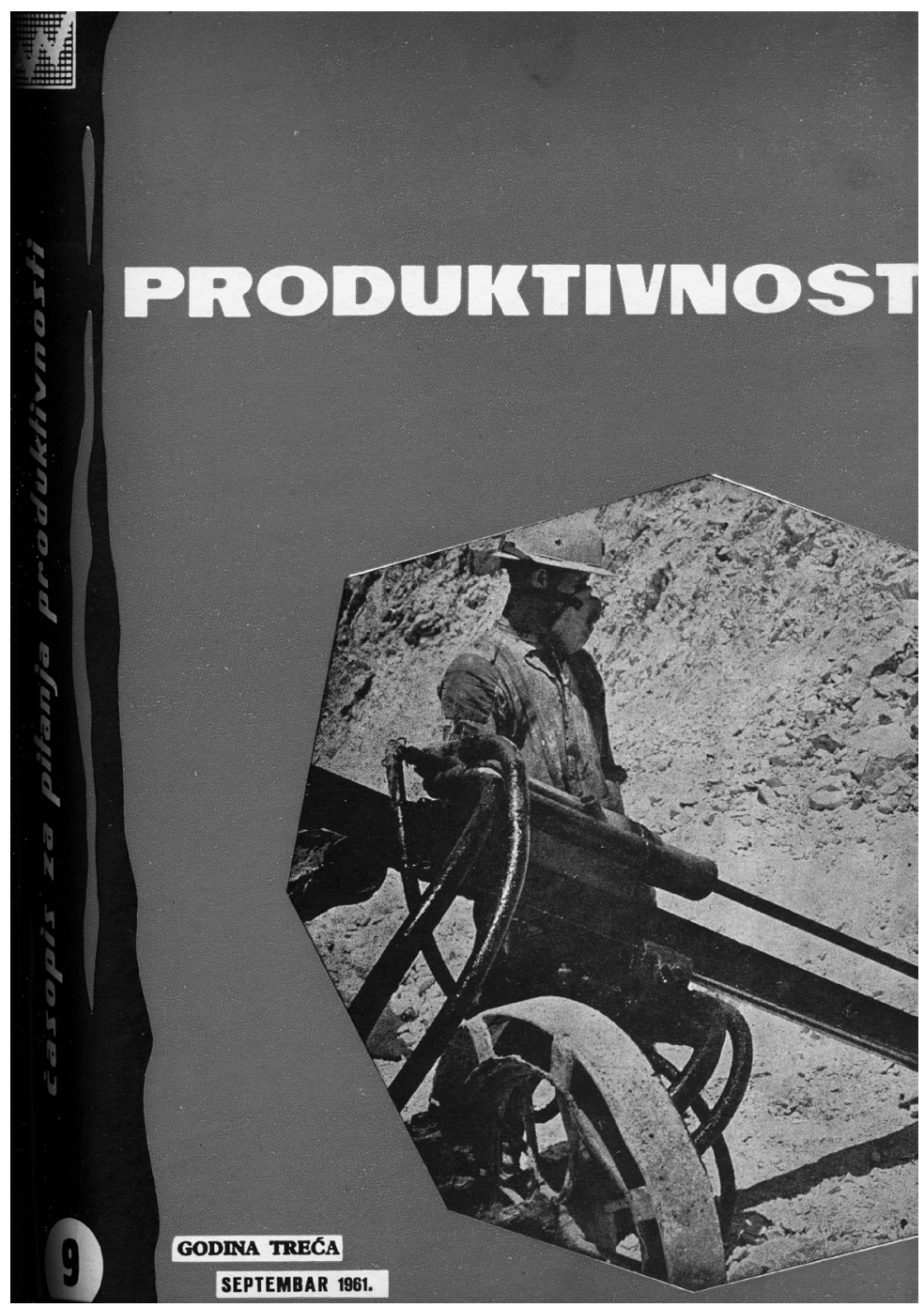

Figure 3 Cover of Produktivnost, no. 9 (September, 1961). 

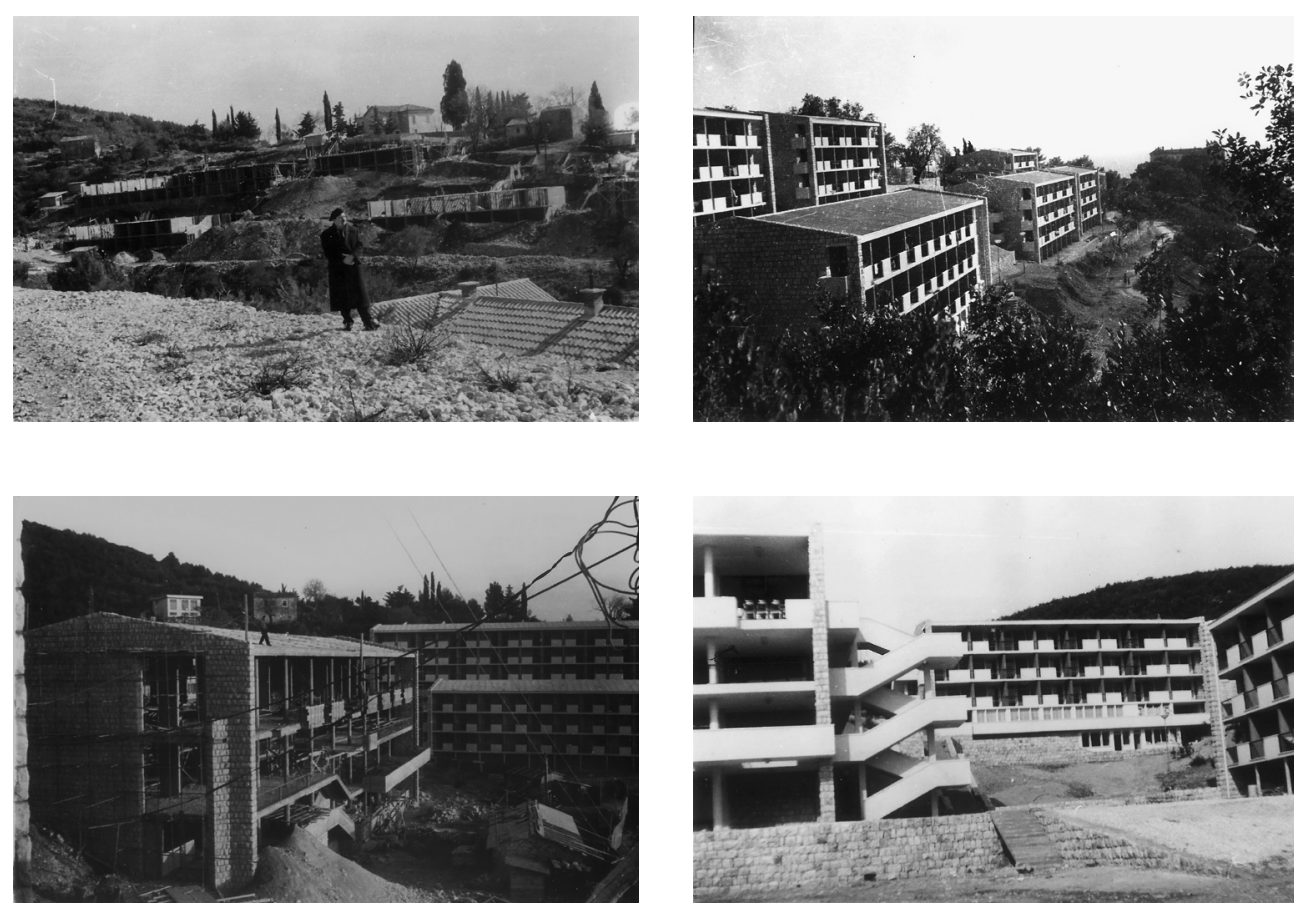

Figure 4 Tourist Settlement in Ulcinj under construction. 
different sizes of the unit for two, three or four people. Besides, the mechanism of differentiation was included in the mathematical system by introduction of the possibility of alternating modular spans $(29 \mathrm{M}, 30 \mathrm{M}, 36 \mathrm{M} 43 \mathrm{M})$, so that the suites of $43 \mathrm{M}$ of width provided, as stated in the text "the types of higher tourist standard". ${ }^{29}$

\section{DESIGNER PRACTICE: THE HOTEL “MEDITERAN" IN ULCINJ}

Same like in the case of previously realized Teacher Training School in Prizren, Tourist settlement in Ulcinj was designed in such way as to enable construction in phases. In the first phase along with the existing building of the hotel "Galeb" there were seven separate pavilions with independent accommodation units constructed. According to the author, in a small town at the periphery of the country within the term of not full seven months a tourist settlement was erected having the capacity 480 berths: the works commenced in October 1961, and were completed in May, 1962. In the second phase, during 1963 and 1964, another two pavilions with hotel suites and the central building with reception desk, restaurant and other public functions were built. Challenging directly the myth on "the architect-individual", designing and construction of the settlement was the result of the active collaboration and coordinated teamwork. Together with Milan Zloković, the design was signed by his son and daughter, architects Đorđe Zloković and Milica Mojović; the client was the tourist company Grand hotel "Galeb" (in the photograph from the period is Ljubo Brnović, the first Hotel Manger); ${ }^{30}$ two construction companies participated in the realization of the design: "Komgrap" from Belgrade, in the first phase, and "Primorje" from Ulcinj, in the second phase of building. ${ }^{31}$

As mentioned in the text on the construction of the hotel which Milan Zlokovic published in 1963 in the magazine Arhitektura urbanizam, particular attention was paid by the designer to the urban layout. ${ }^{32}$ The group of buildings which was formed in the first construction phase, consisting of the independent buildings arranged along the steep slope of the ridge facing the Ulcinj bay and the Old Town, emerged as the result of adjustments made to the relief, unique topography and character of the location. Same like the preceding designs, this one as well resulted from Zloković's profound and inmost understanding of the Mediterranean culture and traditional building principles. The key role which in formation of Zloković's architectural language had had the image and logics of the boat and its correlative in the form of captains' houses in Boka Kotorska, was indicated by Ljilana Blagojević in her analysis of modernism in Serbia in the period between the two World Wars. ${ }^{33}$ As 


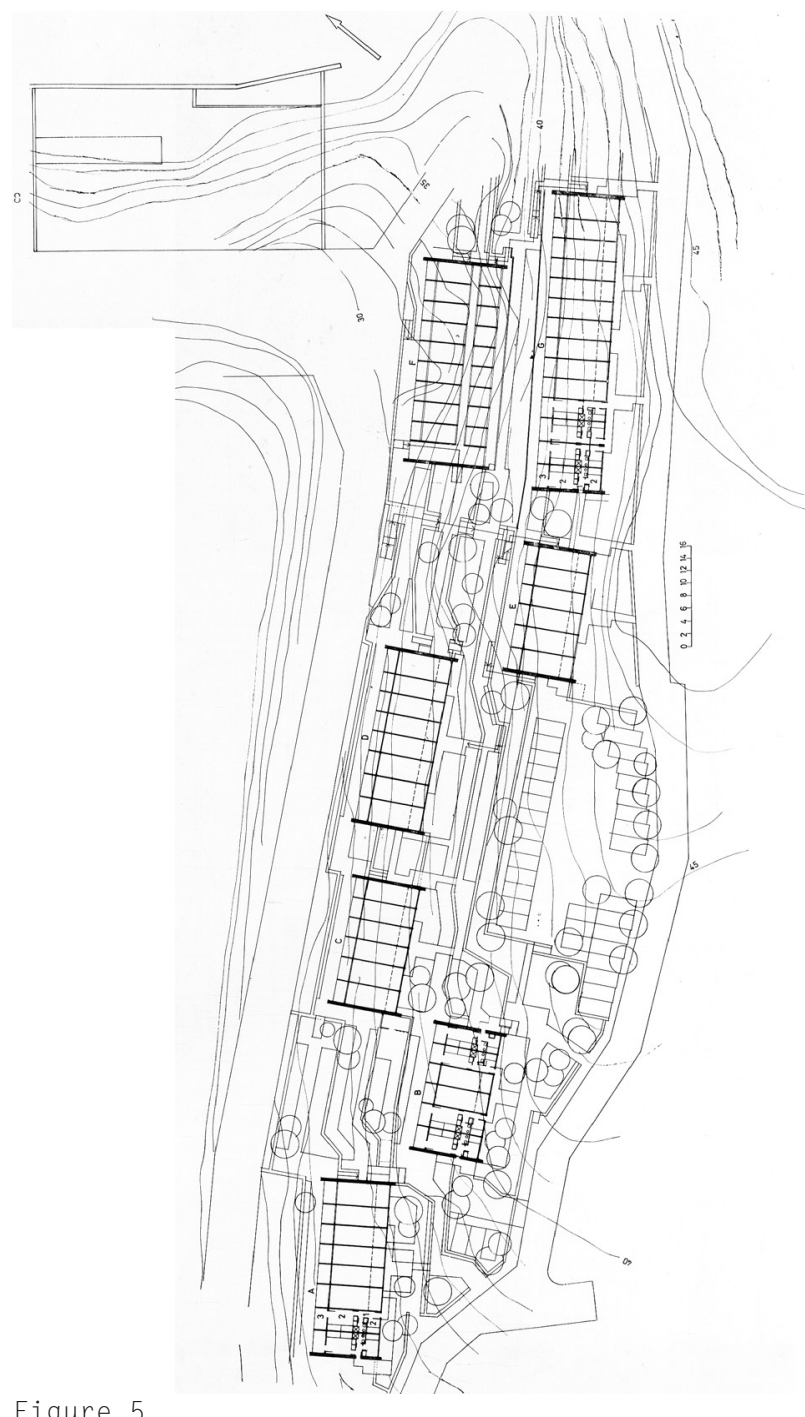

Figure 5

Milan Zloković, Đorđe Zloković and Milica Mojović, Tourist Settlement in Ulcinj. Site plan of the first phases of construction. 


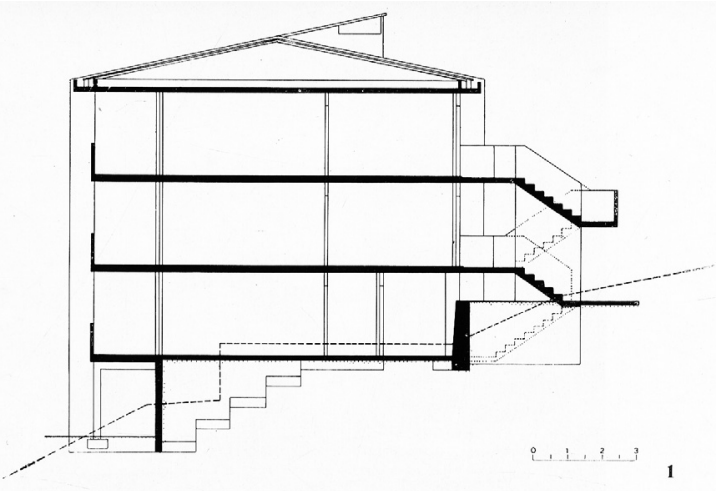

Figure 6 Milan Zloković, Đorđe Zloković and Milica Mojović, Tourist Settlement in Ulcinj. Section and typical apartments. 


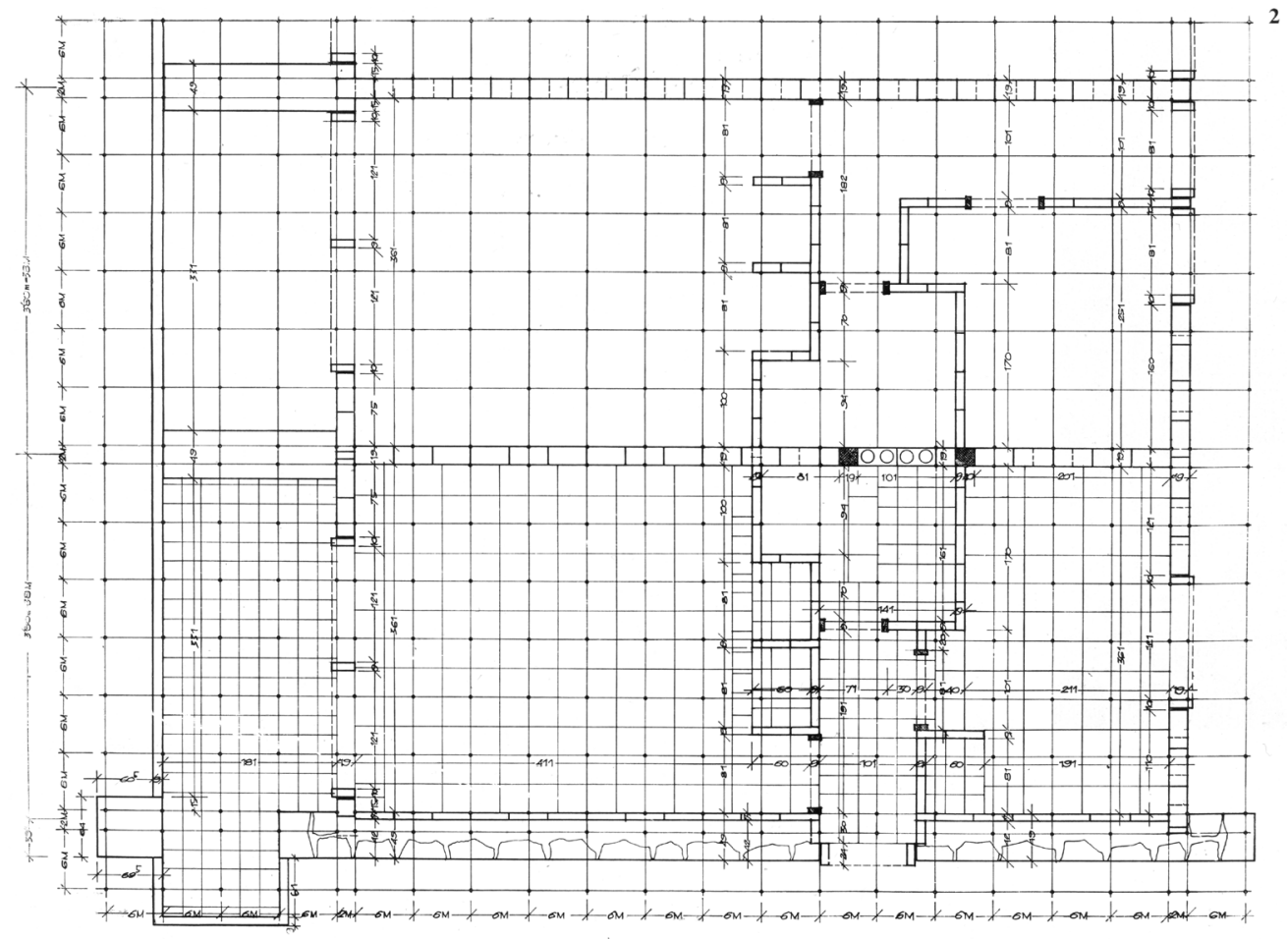

Figure 7

Milan Zloković, Đorđe Zloković and Milica Mojović, Tourist Settlement in Ulcinj. Typical suite: a detail of plan with the diagram of building with modular blocks. 
noted by Blagojević, it was not the sentiment for the patriarchal trade culture, but the identification of the referential historical practice that was in the essence of this assimilation. Rationality, expressed through rigorous economics of the space and forms, represents the common denominator of the traditional Mediterranean houses and Zloković's modern architecture, and the imperative, which, as the fundamental designing principle, in continuity determined also Zloković's postwar designs as well.

The change of the socio-political system and the general conditions of designing and building in the socialist Yugoslavia, however, influenced the change of the relations which Zloković's architecture had established in relation to the context. The logics and aesthetics of the ship were still dominant characteristics of the structure, but the pavilions of the hotel "Mediteran" were not any longer so willing "to sail away", like the strict, abstract, non-contextual and anti-historical architecture of Zlokovic's Pediatric Clinic in Belgrade (1933; 1936-1940) or the National Health Home in Risan (1938-1941) was. ${ }^{34}$ The regular geometrical structure of the buildings and the dynamic forms of the natural landscape were harmonized by benching the slopes of the terrain by means of boundary stones and earth embankments and by sensitive deviations and rotations of abstract geometrical matrices determining the structure and layout of the buildings. Without giving no grounds in view of structural characteristics of the entities, harmonization was restricted to the perimeter zones and was implemented through delicate transformations of ground-floor levels, gable walls and roof planes, as well as by means of the system of external communications providing direct access to the individual hotel units.

In other words, these ships were more firmly anchored, to quote this useful metaphor once more, but not to give way themselves to the provincial ideals of the small town. If Bloch's criticism of functionalistic architecture as the seductive illusion may easily relate to Zloković's key designs originating immediately before the beginning of the World War Two, as suggested by Blagojević, ${ }^{35}$ the designs originating in the postwar period clearly established substantially different, more direct and intensive relations towards the changed social reality. Appropriation of historical and vernacular codes (traditional stone walls, boundary stones, slanting roofs), could be interpreted as giving up the modernistic imperative of auto-referencing, or, like Reyner Banham would formulate it in the criticism of Peter and Alison Smithson, as "too much submission to traditional values", ${ }^{36}$ however this reading would be superfluous and unambiguous. It could rather be stated that in this case there existed inherent antithetic moment in which two parallel processes were simultaneously in 
progress: the radical departure from the empirical reality and intensive communication with the context real conditions, and that this ambivalence was the integral part of Zloković's design method.

The design of the Tourist settlement in Ulcinj was almost completely defined by the previous researches at the Institute of Architecture and Urban Planning. The entities were formed by combinations of two medium modular grids $30 \mathrm{M}$ and $36 \mathrm{M}$ wide. The walls were built with hollow concrete blocks having the dimensions 19/19/39 $\mathrm{cm}(2 \mathrm{M})$ for the bearing walls and 9/19/39 $\mathrm{cm}(1 \mathrm{M})$ for the partition walls. The floor structures $2 \mathrm{M}$ thick were also anticipated in the prefabricated assembly, however, upon the request of the contractor, they were cast on the site. As anticipated in the study, the gable walls (5M) were built with the natural, crushed stone, in a traditional manner, with the face from both sides without rendering, and the buildings covered with corrugated evelite sheets placed over the double-pitched roof structure. Given that "flexible typification" comprised adaptation to the specific aspects of the concrete situation this system of exemplary clarity was not realized dogmatically. Its openness and flexibility can be perceived already at the level of typology:

In the total there are 96 double-room and 48 single-room suites, with separate entrances, sanitary facilities and spacious loggias which all, without an exception, have the coast view and the old fortress view. These suites occupy six buildings. The seventh building, however, was designed with double and single rooms, each with the wash basin; while bathrooms, toilets and showers were provided separately. This building front with sea view has been also designed with loggias. All rooms are equipped with built-in closets. The hot water devices have been installed. ${ }^{37}$

This way also the units of lower standard have been included, in which the same structural and organizational principles were implemented and the same technological standards maintained. This dialectics of unity and differences later on acquired its symbolic expression in the names of pavilion - "villas": "Ljubljana", "Zagreb", "Beograd", "Sarajevo", "Skopje", "Novi Sad", "Pristina" "Titograd" and "Cetinje". ${ }^{38}$

In the second phase two new pavilions ("Opatija" and "Dubrovnik") were constructed as well as the central buildings with reception desk and public functions. The design of the central building was founded on the recommendations for designing of the type restaurant which were also provided in the previous study, but that which singled out this building from the previous 
ones was a free interpretation of the starting presumptions and their original artistic development. In the study it was anticipated that the building would be a two to three storey high, that the restaurant would be located at the last storey and that at the ground-floor, namely interpolation storey (depending on the terrain gradient) there would be the reception desk with the hotel settlement management, public use rooms, dairy restaurant, and diverse shops. The central building of the hotel "Mediteran", however, has four storeys: the great terrain gradient made it possible not only to add another level with the reception desk, but significantly more dynamic organization of two-storey entrance hall with related functions. The terraces, placed lengthwise along the entire front of the building, according to the first plan, were $39 \mathrm{M}=390 \mathrm{~cm}$ in depth; at the asbuilt building the depth of this large loggia was almost doubled $(700 \mathrm{~cm})$, and the space thus defined was connected by stairways and square-shaped openings in horizontal planes creating the effect of three-dimensionality and introduced the time dimension into spatial experience. Thus formed vivid and scenic public space represented a powerful counterpoint to the separated, rationally dimensioned and modestly equipped accommodation units. By rotating one of the exterior stairways, an exciting lateral view of this dynamic spatial structure was provided.

Therefore, Zloković's design method was founded on the system of precise geometrical and numerical laws, but in such way that it did not allow for absolute domination of mathematical system. Same like mathematical formulas, the established modern canons in the architecture of the hotel "Mediteran" were interpreted in a non-dogmatic way, with the critical distance. Stone gable walls and slanting roofs did not mean the return to the pre-modern condition, withdrawal from the original goals and requirements of modernism, but the elements establishing the communication with the local and regional contexts and which functioned as counterpoint to the anonymity of prefabrication and referential point which made the technological and methodological breakthrough clearly visible. This procedure would rather be interpreted as the attempt of more intensive linking of architecture and the social reality, striving that architecture, as the autonomous discipline, would become useful in the true meaning of the word and socially committed, without concessions and compromises. This way, Zloković's architecture actually becomes more radically modern, harmonized with the original theory of modernism, clearly detached from the prewar trade practice and, at the same time, sensitive to the special particularities of the context and regional characteristics of location. ${ }^{38}$ 


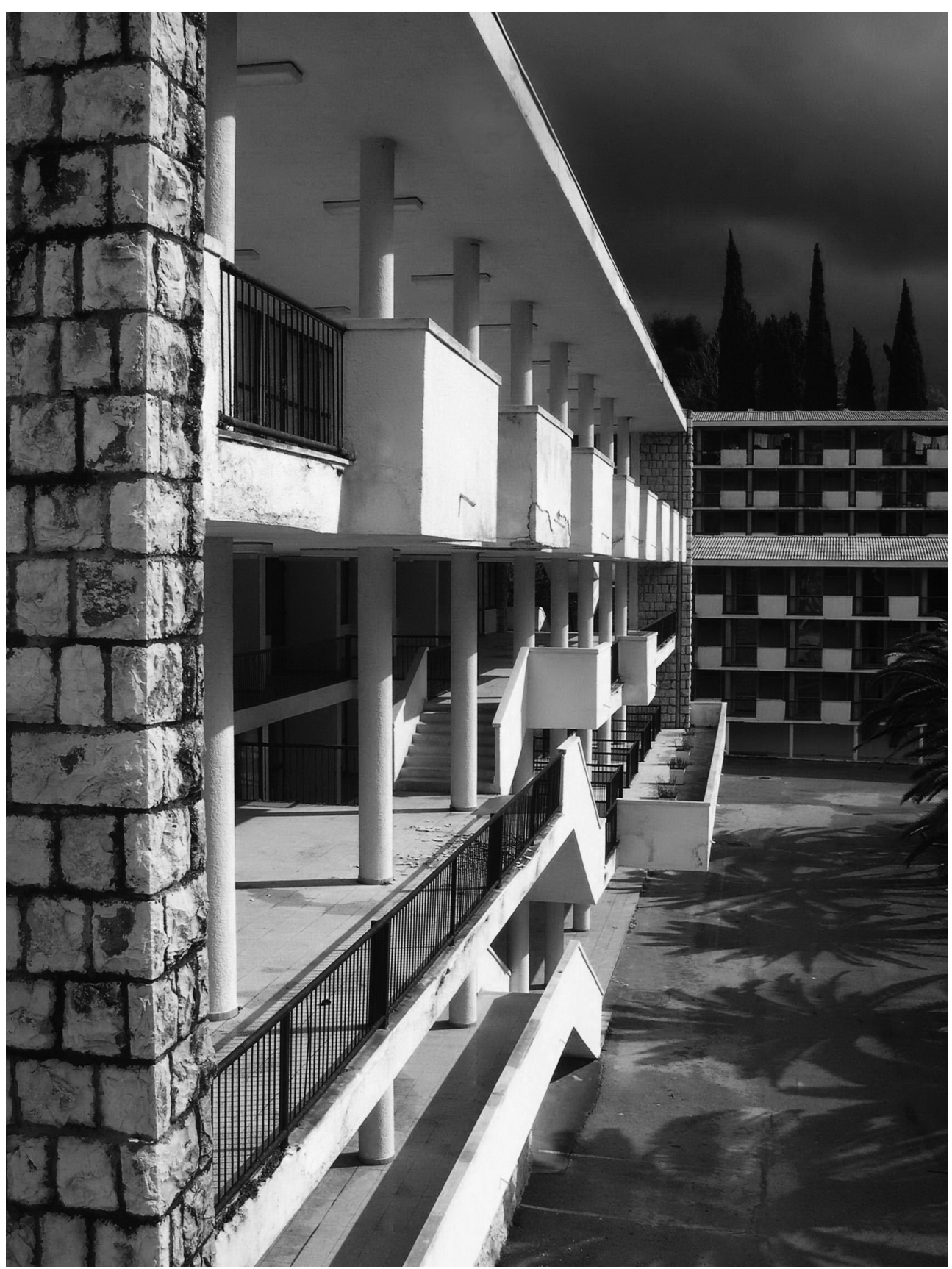

Figure 8 Tourist Settlement in Ulcinj. Front of the central building and villa "Titograd". 


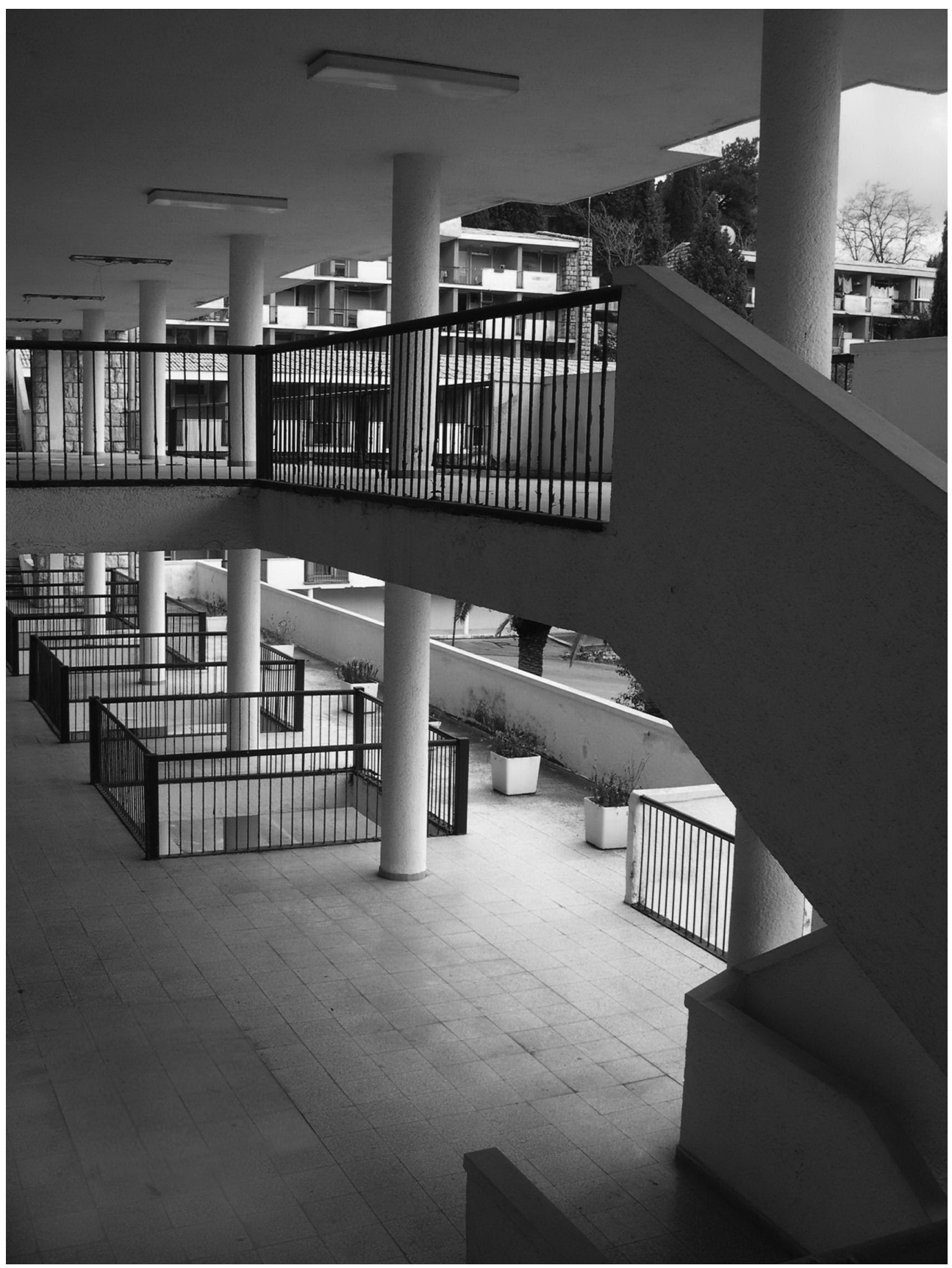


Inherent dialectics of Zloković's architecture is identified by Blagojević in the designs originating between the two World Wars: this architecture is "abstract and rational, yet deeply human, functional and pragmatic, yet artistic, self-referential in its modernity, yet relating to the classical rules of proportions." 39 When it concerns Zloković's postwar designer practice, this series of contradictions would be extended with dialectic pair to: autonomycommitment. If, as suggested by Neumann, the theory of proportions in the international debate in the first decade following the end of the World War Two served first of all as the means of the architects to preserve their social positions and insure their own competencies, and only then as the means for incorporation into the contemporary social processes, it could be stated that in the groundwork of Zloković's methodological action there was an inverse situation and that this inversion could be in principle compared to the progress in the artistic production about which it was written by Walter Benjamin, and which arrived with the invention of the film. Benjamin's parabola on the painter-magician and the cameraman-surgeon speaking of diverse ways of setting corresponding distance in relation to the empirical reality, could indirectly explain the specific aspect of Zlokovićs author position:

The magician maintains the natural distance between the patient and himself; though he reduces it very slightly by the laying on of hands, he greatly increases it by virtue of his authority. The surgeon does exactly the reverse; he greatly diminishes the distance between himself and the patient by penetrating into the patient's body, and increases it but little by the caution with which his hand moves among the organs. ${ }^{40}$

As the artists, namely architects-surgeons in the seminal study by Manfredo Tafuri, Theories and History of Architecture, Walter Gropius, Le Corbusier and Mies van der Rohe were mentioned, and in the text it was implicitly pointed out that they could also be some other representatives of the non-dogmatic work of the Russian constructivism. ${ }^{41}$ 

konstruisanju zgrada. Primer praktične primene na turističkim objektima za crnogorsko primorje kao sredstva produktivnijeg građenja" (An example of practical application on tourist buildings for Monte Negro coast as the means of more productive building), Produktivnost (Beograd), issue. 9 (1961), pp. 583-593.

In the form of proposal/recommendation inspired by the comment of Albert Einstein on Le Corbusier's modulor, "Systems of Proportion makes good design easier and bad design more difficult", this resolution should have confirmed/provided the consensus among the architects on the significance of the proportional systems. The results of voting, 48:60, stated that the predominant stream was the one which considered this theme to be passé at the time. On more detailed context of this debate and its corollaries see: Rudolf Wittkower, "The Changing Concept of Proportion", Idea and the Image: Studies in the Italian Renaissance (London: Thames and Hudson, 1978), pp. 109-123. 
idea of the civil engineer Branko Žeželj, conceived and developed the IMS prefabricated skeleton system for the construction of residential and public buildings, which was to become the most widely applied building technology in Yugoslavia. The first building in IMS system was erected in Novi Beograd in 1957, and till 1982, approximately 60000 residential units were built, as well as a series of schools, administrative buildings, hotes and other public buildings. Also, by applying this technology numerous buildings in Italy, Angola. Bulgaria Egypt, Ethiopia, China, Cuba, Georgia, Hungary, Philippines, Russia and Ukraine were built. "IMS System. Prefabricated Skeleton System of Construction of the Residential and Public Buildings", the inernal publication of the Institute for Testing of Materials of Serbia, not datad.

The subject of this paper is the design methodology of Milan Zloković, therefore all texts and designs in which besides him several more authors participated on certain occasions will be interpreted as the integral part of his creative opus. Still, this approximation should be borne in view, given that the contribution of the other actors was of substantial value, particularly so in his later designs

On Zloković's seminal role in the origination and development of modern architecture in Serbia see: Ljiljana Blagojević, Modernism in Serbia: The Elusive Margins of Belgrade Architecture 1919-1941. Cambridge, Mass.: The MIT Press, 2003, pp. 191-225. On the dynamic relation between the theoretical and practical work Blagojević wrote: “As Zloković himself seldom referred to his own projects in his theoretical works, current historiography has divided the two into separate compartments, with the praxis deemed representative and favored against the loss of direction in his theory. It is my contention that the constituent facts of Zlokovićs architecture and its elaboration in building can be detected only through a reconciliation of his practice and his theory. The key to Zloković's game is in his work, in which the practices of modernity and of tradition, and of design and theory, are interrelated, without either claiming precedence over the other." (p. 197)

Bogdan Bogdanović, "Povodom dodeljivanja nagrade za životno delo Milanu Zlokoviću" (ON the occasion of conferring the award for life work to Milan Zloković), Arhitektura urbanizam (Beograd), issue. 22-23 (1963), p. 106.

Out of thirty five diverse designs from the postwar period, as many were listed in the text by Zoran Manević, only three Zloković's designs have been realized. Zoran Manević, Zloković (Beograd: Institut za istoriju umetnosti, Muzej savremene umetnosti, Institute of History of Art, Museum of Contemporary Art 1989), pp. 37-38

At the First International Congress on Proportions in Art, held in Milan in the period 27-29 September, 1951, it was concluded that a type of controlling or regulative systems of proportions was desirable, however, the Congress, according to Rudolf Wittkower, did not provide any results on the work of the younger generation. Wittkower, :The Changing Concept of Proportion", p. 121. Nikola Dobrović, "Animomorfni stvaralački proces" (Animomorphic creative process) u: Savremena arhitektura 5 (Beograd: Zavod za izdavanje udžbenika SR Srbije, 1971), p. 105. Opposing the academic methods of scientific aesthetics of Milutin Borisavljević, Dobrović at the same time denied also the significance of any geometrical system of modular coordination. As the antithesis of the academic determinism, Dobrović formulated the "spiritual module" syntagm , accentuating thereby the role of intuition in the creative process. That is "the abstract space rule (which) has no association with geometrics, but is the means for internal perception of qualitative phenomena at the spiritual screen of the creator." Ibid., p. 106. More details on Dobrović's relation in respect to this theme see: Marija Milinković, "Duhovni modul" arhitekte Nikole Dobrović: analiza modularne koordinacije na primeru dva projekta iz dubrovačkog perioda" ("Spiritual module" of the architect Nikola Dobrović: analysis of modular coordination on the example of two designs from the Dubrovnik period" Arhitektura urbanizam (Beograd), issue 16-17 (2005), pp. $87-103$

11 Besides the text of Ljiljana Blagojević on Zloković's practice in the period between the two wars see Zoran Manević, "Naši neimari (Our Builders) 2: Milan Zloković”, Izgradnja (Beograd), issue. 7 (1980), p. 50; Marina Đurđević "Zivot i delo arhitekte Milana Zlokovića" (The Life and Work of 
the Architect Milan Zloković), Godišnjak grada Beograda, vol. XXXVIII (Beograd: Muzej grada Beograda, 1991), p. 161; Vanja Panić, "Afirmacija principa moderne arhitekture i specifičnosti njihove primene u Srbiji na primeru javnih objekata arhtekte Milana Zlokovića” (Affirmation of the Principle of Modern Architecture and the Specific Aspects of its Application in Serbia on the Example of Public Buildings of the Architect Milan Zloković), Master's thesis defended at the Faculty of Architecture of the University of Belgrade, 2010.

Đurđević, “Život i delo arhitekte Milana Zloković”, p. 161.

Manević, "Naši neimari 2: Milan Zloković", p. 50

Le Korbizije, Toward an Architecture, trans. John Goodman (Los Angeles: Getty Publications, 2007), p. 254.

Le Corbusier, Le Modulor. Essai sur une mesure harmonique à l'échelle humaine applicable universallment a l'architecture et la mécanique (Paris: Denoel Gonthier, 1977), p. 41.

Milan Zloković, »Uticaj prorporcijskog sistema Blondelove kapije Sv. Deni-a u Parizu na nedovoljno rasvetljeni problem proporcija u arhitekturi« (The Influence of the Proportional System of Blondel's gate of Saint-Denis in Paris upon the Insufficiently Clarified Problem of Proportions in Architecture). Godišnjak Tehničkog fakulteta Unverziteta u Beogradu za 1946 and 1947. Beograd: Tehnički fakultet Univerziteta u Beogradu, 1949, pp 45-58

Ibid., p. 56

In 1949 the influential book by Rudolf Wittkower Architectural Principles in the Age of Humanism, was printed as well. Same like Wittkower, Zloković was in this text in the search for the broader foundation of contemporary practice, essential for establishing general values, relevant for the development of the modern architecture. Rudolf Wittkower, Architectural Principles in the Age of Humanism (New York, London: W. W. Norton \& Company, 1971). On influence of Wittkower's book on modern architecture see: Henry A. Millon, "Rudolf Wittkower, Architectural Principles in the Age of Humanism: Its Influence on the Development and Interpretation of Modern Architecture", Journal of Society of Architectural Historians, vol. 31, no. 2 (May, 1972), pp. 83-91.

Richard Padovan, Proportion. Science, Philosophy, Architecture (London and New York: E\&FN Spon, 1999), p. 38

See particularly the texts of Milan Zloković, "Uticaj recipročnog zalančavanja harmonijskih razmera na proporcijski sklop izvesnog fasadnog sistema" (The Effect of Reciprocal Chaining of Harmonious Proportions upon Proportional Entity of a Certain Facade System). Tehnika (Beograd), issue. 6, 7 (1954), pp. 833-840, 1001-1006. and Milan Zloković, 'Integrisanje 'Modulor'-a u internacionalni modularni sistem" (Integrating 'Modulor' into International Modular System). Arhitektura urbanizam (Beograd), issue. 6 (1960), pp. 28-31.

On Zloković's published theoretical papers see : Tatjana Purić-Zafiroski, »Prorporcijska analiza u tekstovima arhitekte Milana Zlokovića« (Proportional Analysis in the texts of the Architect Milan Zloković), Flogiston (Beograd), issue 11. (2010), pp 129-149.

International Bureau for Standardization in 1957 in Paris adopted the measure of the basic building module of $1 \mathrm{dm}=10 \mathrm{~cm}=1 \mathrm{M}$ in the countries with metric system of measures, namely $4 "=10,16$ $\mathrm{cm}$ in the United States of America and in Great Britain. Zloković, however, considered that the IUA recommendation of 1954 was ill-advised and that anthropomorphic measure of $5 " \approx 12,5 \mathrm{~cm}$ was more suitable as the international modular unit. Milan Zloković, "O problemu modularne koordinacije mera u arhitektonskom projektovanju" (On the Problem of Modular Coordination of Measures in Architectural Design). Tehnika (Beograd), issue. 2 (1954), pp. 169-182.

Milan Zloković, "Kritički osvrt na modularne mere standardnih elemenata 'Durisol' putem analize dve fasadne kombinacije u oktametarskom sistemu" (Critical Review of the Modular Measures of 'Durisol» Standard Elements by Analyzing Two Facade Combinations in Octometric System). Tehnika (Beograd), issue. 5 (1955), pp. 331-227

Milan D. Zloković, Milica M. Mojović and Đorđe M. Zloković. "Nova učiteljska škola u Prizrenu. Studijska primena modularne koordinacje mera na projekat zgrade montažnog tipa" (The New Teacher Training School in Prizren. The Study Application of Modular Coordination of Measures 
on the Design of the Prefabricated Type Building) Zbornik radova Instituta za arhitekturu $i$ urbanizam (Beograd: Institut za arhitekturu i urbanizam, 1961), pp. 15-22.

Zloković's text on construction of the new tourist colony in Ulcinj was part of the thematic double issue of the magazine Arhitektura urbanizam which was entirely devoted to this theme. On the broader context of the planned construction of the Yugoslav coast see: Dimitrije Perišić, "Prostorno planiranje turističkih područja i naselja" (Spatial Planning of Tourist Regions and Colonies), Arhitektura urbanizam (Beograd), issue. 22-23 (1963), p. 5 and Aleksandar Đorđević and Uroš Martinović, "Studija prostornog plana turističkog područja opštine Budva" (Study of the Spatial Plan of the Tourist Region of the Municipality of Budva), ibid., p. 36. Zlokovići, “Značaj modularne koordinacije u projektovanju i konstruisanju zgrada” (Significance of Modular Coordination in Building Design and Construction), p. 583

Ibid.

Ibid., p. 584.

Ibid., p. 591.

Ljubomir Brnović was born in the village of Bobija, in Rijeka Crnojevica, in 1921. He moved to Ulcinj with his family in 1928. Before the World War Two he was employed as the laborer with the hotel "Galeb", in the job of heating maintenance, and in 1943, he joined the National Liberation War. Following the demobilization, in 1946, he was again employed with the hotel "Galeb", as the head clerk, and at the age of twenty-six (in 1949) he was appointed the manager of this hotel. At the beginning of ninety-sixties, the complex of the tourist buildings surrounding the hotel "Galeb", the newly built hotel "Mediteran", the hotels "Jadran" and "Republika" became a sole Hotel company "Ulcinj", later on "Ulcinjska rivijera". Ljubo Brnović was in the management of this hotel till 1967. He was the national representative in the Parliament of Monte Negro, the Chairman of the Board of Managers of the company "Montenegroturist" and the Chairman of the Red Cross of Monte Negro. He passed away in 1992. In the text on the results of the work on the design of the Teacher Training School in Prizren, Milan Zloković also emphasized the significance and role of the various participants in designing and construction of this building. Besides his collaborators in the design (the architect Predrag Zrnić, who was the author of the itemized bill of quantities and the plan of water engineering installations, the engineer Ladislav Vicek - the central heating installations plan and the engineer Slobodan Stojiljković - the electrical installations plan), and the participants in realization (construction company "Šar" from Prizren and the architect Ivan Prokić who was entrusted with the professional supervision at the construction site), Zloković emphasized that for realization of this design "the sincere dedication of the representatives of the local authorities, Mehmet Malici and Ali Dauta, as well as the Principal of the Teacher Training School in Prizren - Radomir Ristić" was also rather significant. Zloković et al., "Nova učiteljska škola u Prizrenu", p. 22 Milan Zloković, "Novo turističko naselje u Ulcinju" (The New Tourist Colony in Ulcinj), Arhitektura urbanizam (Beograd), issue. 22-23 (1961), pp. 47-50. Blagojević, Modernism in Serbia, pp. 205-225.

Ibid., p. 210.

Ibid., p. 209. Blagojević cited the text from Bloc's book Das Prinzip Hoffnung in which Bloch rejected the functionalistic architecture the »purity« and »sincerity« of which were an illusion. Openness, transparency and lightness of the modern architecture, believed Bloch, was in contradiction with the social reality of the ninety-thirties: "The broad window, full of nothing but outside world, needs an outdoors full of attractive strangers, not full of Nazis; the glass door right down to the floor really requires sunshine to peer and break in, not the Gestapo." Ernst Bloch, The Principle of Hope, trans. Neville Plaice, Stephen Plaice and Paul Knight (Cambridge, Mass.: The MIT Press, 1986), p. 733. 
During ninety-nineties the Tourist colony lost its primary function. A part of the hotel units was used as residential space. During 2005 the hotel was privatized, and thereafter reconstructed. Three lowest standard buildings were destroyed (»Beograd«, »Titograd« and »Opatija«), and in the remaining pavilions the joinery was replaced and air-conditioning system installed. Villa »Dubrovnik" should also be destroyed. In their place the construction of the new hotels » of contemporary tourist standards « has been anticipated. The centre of social gatherings was from the broad terraces of the standard type restaurant relocated to the newly built pool. During reconstruction, the changes on the central building with the restaurant were minimal.

"The architecture of Milan Zloković resists simple interpretation, for it is abstract and rational yet deeply humanist, functional and pragmatic yet artistic, self-referential in its modernity yet relating to the classical rules of proportion.” Blagojević, Modernism in Serbia, p. 221.

Walter Benjamin, "The Work of Art in the Age of its Mechanical Reproduction", in Stephen David Ross, ed., Art and Its Significance (New York: State University of New York, 1994), p. 534.Manredo Tafuri, Theories and History of Architecture, trans. Giorgio Verrecchia (London:

For their generous help in providing research and illustration material for this paper I would like to thank Jovan Nikolić, Vaso Radović, Ljiljana Bulatović, Žarko Brnović, Perica Pejović, Sreten Nikolaides, Dragan Mičetić and Branko Nikolić.

Figure 1 Hotel Mediteran Resort, Ulcinj. Courtesy Branko Nikolić.

Figure 2 Zbornik radova Instituta za arhitekturu i urbanizam (Beograd: Institut za arhitekturu i urbanizam, 1961), p. 21.

Figure 3 Produktivnost (Belgrade), no. 9 (September, 1960), front page.

Figure 4 Private collection. Courtesy Žarko Brnović.

Figure 5-7 Arhitektura urbanizam (Beograd), br. 22-23 (1961), p. 47-50.

Figure 8-9 Photograph by Anna Weber, 2004.
} 